\title{
Super-reducing conditions in ancient and modern volcanic systems: implications for the carbon budget of the deep lithosphere
}

\author{
William L. Griffin ${ }^{1}$, Sarah E.M. Gain ${ }^{1}$, Jinxiang Huang ${ }^{1}$, Yoann Greau ${ }^{1}$, Vered Toledo ${ }^{2}$ and \\ Suzanne Y. O'Reilly ${ }^{1}$ \\ ${ }^{I}$ ARC Centre of Excellence for Core to Crust Fluid Systems (CCFS) and GEMOC, Earth and Planetary \\ Sciences, Macquarie University, NSW 2109, Australia; bill.griffin@mq.edu.au; sarah.gain@mq.edu.au; \\ jinxiang.huang@mq.edu.au; yoann.greau@mq.edu.au; sue.oreilly@mq.edu.au \\ ${ }^{2}$ Shefa Yamim (A.T.M.) Ltd., Netanya 4210602, Israel gold101@netvision.net.il
}

\section{Introduction}

Estimates of the oxygen fugacity $\left(f \mathrm{O}_{2}\right)$ of the cratonic subcontinental lithospheric mantle (SCLM) range from above the quartz-fayalite-magnetite (QFM) buffer to just above the iron-wustite (IW) buffer, and generally decrease with depth. While several lines of evidence suggest that the sublithospheric mantle may be constrained by the IW buffer (the presence of metallic Fe), there also is evidence that at least localized volumes of siginficantly lower $f_{2}$ must exist within the SCLM, and perhaps within the deeper mantle. In this contribution, we describe a remarkable example of super-reducing conditions in an offcraton volcanic setting (Griffin et al., 2016a), and discuss its implications for other tectonic settings, and for the transfer of carbon and hydrogen from the deeper mantle.

\section{Super-reducing conditions in a Cretaceous volcanic system, Mt Carmel, Israel}

Aggregates of hopper-formed crystals of Ti-rich corundum are abundant in Upper Cretaceous basaltic pyroclastic rocks (vent breccias, tuffs) exposed on Mt Carmel near Haifa, Israel. Melt pockets trapped within and between corundum crystals contain mineral assemblages ( $\mathrm{SiC}$ (moissanite), $\mathrm{TiC}, \mathrm{Fe}-\mathrm{Ti}-\mathrm{Zr}$ silicides/phosphides and native $\mathrm{V}$ ) that require $\mathrm{P} \geq 1 \mathrm{GPa}, \mathrm{T}=1500-1100{ }^{\circ} \mathrm{C}$ and extremely low $f \mathrm{O}_{2}$ ( $\Delta \mathrm{IW}$-10 to-12) (Griffin et al., 2016a). Mineral parageneses suggest that the corundum and the low$f \mathrm{O}_{2}$ assemblages developed through interaction of basaltic magmas with mantle-derived $\left(\mathrm{CH}_{4}+\mathrm{H}_{2}\right)$ at high fluid/melt ratios, leading to progressive lowering of $f \mathrm{O}_{2}$.

A schematic illustration of the process is shown in Figure 1; this model envisions a magma chamber being flushed by a steady supply of $\mathrm{CH}_{4} \pm \mathrm{H}_{2}$, but other configurations are possible. The material described here comes from at least 8 different volcanoes, with eruptions spread over ca $10 \mathrm{Ma}$, providing snapshots of similar magmatic systems erupted at different stages of their evolution, and has been used to reconstruct the evolution of a single synthetic system. The early oxidation of $\mathrm{CH}_{4}$ may have led to the precipitation of abundant, commonly vesicular, wustite found as ejecta in the pyroclastics; this suggests $f \mathrm{O}_{2}$ at or below the QFM buffer. The $\mathrm{CO}_{2}$ released by this reaction may in turn have driven the precipitation of abundant high-Mg calcite, also found in the ejecta; this could continue to $f \mathrm{O}_{2}$ as low as the EMOD/G buffer. The progressive lowering of $f \mathrm{O}_{2}$ to the IW buffer is marked by the appearance of a suite of mutually immiscible melts: native $\mathrm{Fe}, \mathrm{Fe}$-oxide/silicate melt and Ti-oxide/silicate melt. This reaction appears to have removed most of the FeO from the system; none of the silicate phases in the trapped melts (see below) have significant contents of Fe. The removal of the $\mathrm{Fe}-\mathrm{FeO}$ buffer would allow $f \mathrm{O}_{2}$ to decline (rapidly?) to the levels $(\Delta \mathrm{IW}=-6$ to -8 ) where $\mathrm{SiC}$ could precipitate. This would desilicate the melt (now dominated by $\mathrm{CaO}-\mathrm{Al}_{2} \mathrm{O}_{3}-\mathrm{MgO}$ ), driving it into the field where corundum is on the liquidus. The hopper form of the corundum aggregates implies $\mathrm{Al}_{2} \mathrm{O}_{3^{-}}$ supersaturation, causing the rapid growth of corundum, and the trapping of melt pockets, some of which contain silicide melts that precipitated abundant $\mathrm{TiC}$. The desilication process apparently continued to near-completion, leading, in some cases, to a coarse-grained assemblage of hibonite $\left(\mathrm{CaAl}_{12} \mathrm{O}_{19}\right)+$ grossite $\left(\mathrm{CaAl}_{6} \mathrm{O}_{10}\right)+\mathrm{MgAl}$ spinel + fluorite + native $\mathrm{V}$, at $f \mathrm{O}_{2} \leq \Delta \mathrm{IW}-11$. Many of the larger corundum aggregates are cut by breccia veins of amorphous (commonly vesicular) carbon, and this material also 
occurs in parallel-sided veinlets down to the sub-micron (TEM) scale, emphasising the important role of carbon in the evolution of these systems.

\section{Not a unique occurrence}

Similar mineral assemblages (+ diamond) occur in the "ophiolitic" peridotites of the Yarlong-Zangbo and Bangong-Nujuang suture zones (southern Tibet; Xu et al., 2009; Zhang et al., 2016; Griffin et al., 2016b; F. Xiong et al., 2017) and the Polar Urals (Yang et al. 2016). In each of these cases, as in the Mt Carmel example, most of the more highly reduced phases, including nitrides, silicides and

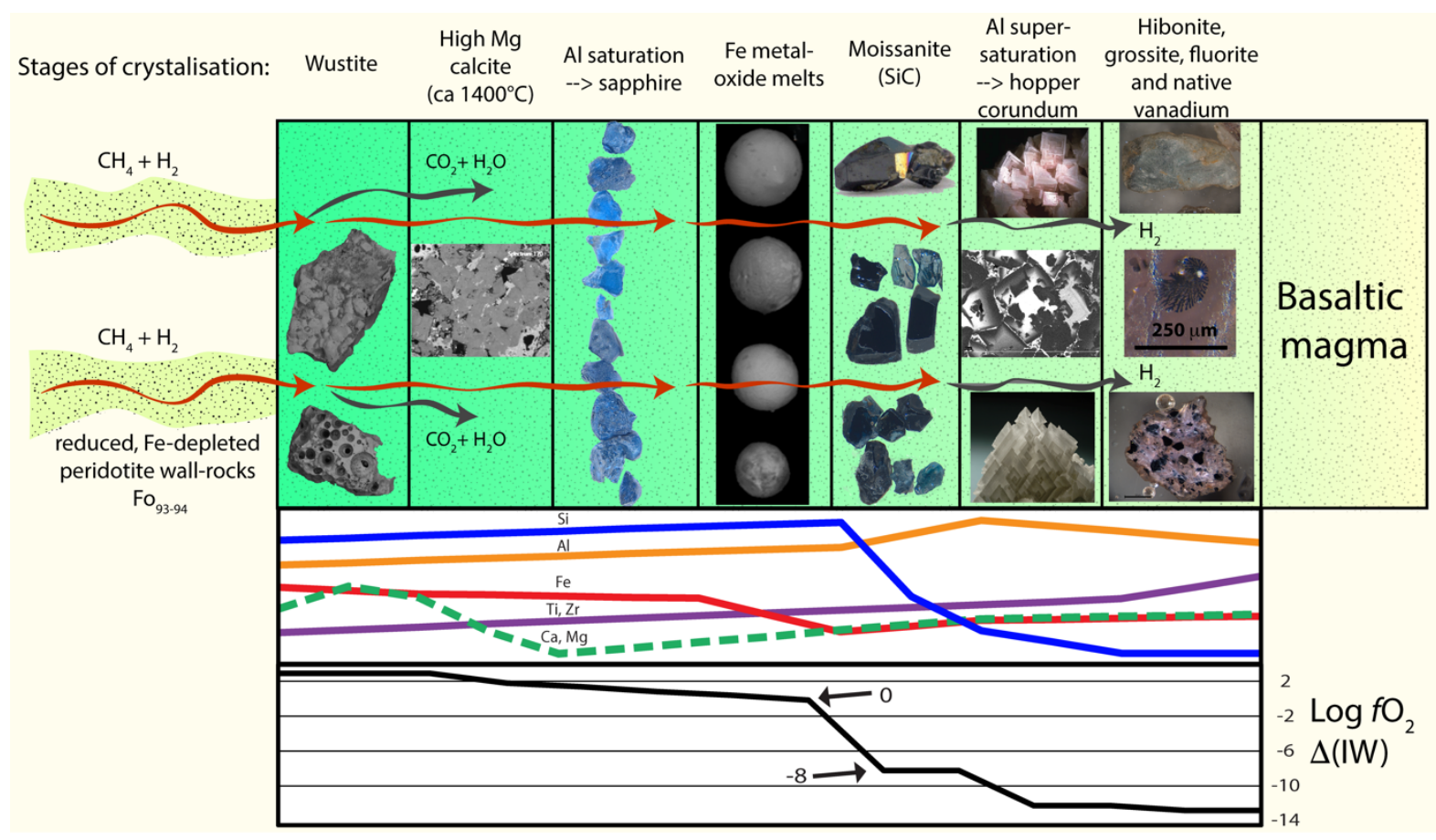

Figure 1. Model for the evolution of the Mt Carmel corundum-SiC system(s), as a progressive interaction between mantle-derived volatiles $(\mathrm{CH} 4 \pm \mathrm{H} 2)$ and a basaltic magma. The evolution of the melt composition and the $f \mathrm{O}_{2}$ of the system is illustrated schematically in the lower panels; the curves for elemental abundance are not to scale. The most important aspects are the drop in $\mathrm{Fe}$ (especially $\mathrm{FeO}$ ) at the IW buffer, the rapid desilication of the melt following the onset of $\mathrm{SiC}$ crystallization, and the extremely low $f \mathrm{O}_{2}$ required by the presence of abundant native $\mathrm{V}$ in the hibonite-grossite assemblage. The incongruent melting of anorthite suggests $\mathrm{P} \geq 9 \mathrm{~kb}$, while phase relationships in immiscible silicide melts indicate $\mathrm{T}=1500-1200{ }^{\circ} \mathrm{C}$.

carbides, are found as inclusions in grains of Ti-rich corundum. The main difference between the "ophiolitic" and the Mt Carmel occurrences is that some carbon in the former occurs as diamond (in breccias of amorphous carbon; Yang et al. 2014; Zhang et al. 2016). Q. Xiong et al. (2017) therefore have suggested that the "ophiolitic" occurrences reflect crystallization in late-magmatic systems related to the rapid emplacement of the host peridotites to shallow depths (McGowan et al., 2015; Griffin 2016b). Similar processes probably are occurring today beneath the Kamchatka volcanic arc, where mafic pyroclastic volcanic rocks carry diamond, $\mathrm{SiC}$ and Ti-rich corundum (Gordeev et al., 2014).

The streaming of low- $f \mathrm{O}_{2}$ fluids from the deep upper mantle thus may accompany many types of deepseated volcanism, especially in tectonic situations (continental collision zones, deep subduction zones, major transform faults) that allow the rapid ascent and focussing of deep-seated magmas. If the $f \mathrm{O}_{2}$ of the deep upper mantle is controlled by the IW buffer, then C-O-H fluids will be dominated by $\mathrm{CH}_{4}+\mathrm{H}_{2}$, like those trapped in metal-bearing Type II diamonds (Smith et al., 2016). The rapid transport of such fluids to shallower depths as components of deep-seated magmas (including kimberlites) is thus inferred to produce local, perhaps transient, volumes of low- $f \mathrm{O}_{2}$ assemblages. 
$\mathrm{SiC}$ is a key indicator for these processes; it is widespread in Siberian kimberlites, and the small number of reports from S. African kimberlites could simply reflect different approaches to the study and processing of kimberlites. However, in both cratons, $\mathrm{SiC}$ occurs as inclusions in diamond, and we have separated $\mathrm{SiC}$ from Roberts Victor eclogites, apparently associated with the metasomatism that generated diamonds in these rocks. The most common inclusion in $\mathrm{SiC}$ from all of these localities is silicon metal, with morphologies suggesting trapping as a liquid, which subsequently commonly exsolved $\mathrm{FeSi}_{2}$ and related phases; these are high-temperature phases $\left(1400-1500{ }^{\circ} \mathrm{C}\right)$ and thus are not related to late serpentinization. The extremely low $f \mathrm{O}_{2}$ required for the formation of $\mathrm{SiC}$ strongly suggests the presence of $\mathrm{H}_{2}$, which could be generated by the partial oxidation of $\mathrm{CH}_{4}$ and the deposition of diamond (i.e. $\left.\mathrm{SiO}_{2}+3 \mathrm{CH}_{4} \rightarrow \mathrm{SiC}+\mathrm{C}+3 \mathrm{H}_{2}+\mathrm{CO}_{2}\right)$. The isotopically light carbon $\left(\delta^{13} \mathrm{C}=-25\right.$ to -33$)$ of the $\mathrm{SiC}$ in the Mt Carmel samples (and kimberlitic $\mathrm{SiC}$ worldwide) is similar to that in the Tibetan diamonds and some Transition-Zone diamonds, and may reflect the composition of abiotic methane in the deep upper mantle.

\section{Other implications}

Redox melting in the presence of abundant $\mathrm{CH}_{4} \pm \mathrm{H}_{2}$, rather than simply carbon, may be more efficient; it may also involve the desilication of wall rocks and their melts, and the production of Al-rich lithologies such as corundum eclogites with negative Eu anomalies. We suggest that all of these processes would accompany the arrival at the SCLM of kimberlites or other melts generated in the deep upper mantle or Transition Zone, and may have contributed significantly to the carbon budget of the lower lithosphere through time.

The recognition that $\mathrm{CH}_{4} \pm \mathrm{H}_{2}$ may accompany melts rising from a deeper, metal-saturated mantle also suggests an explanation for the zones of high conductivity that mark the tracks of mantle-derived magmatic systems (from kimberlites to Bushvelds). The oxidation of $\mathrm{CH}_{4}$ in rising fluids could propogate networks of microveinlets of amorphous carbon (even if later recrystallized to other forms), which might provide the fine-scale connectivity of conductive material in some mantle domains implied by the striking MT images now becoming more widely available.

\section{References}

Gordeev EI, Karpov GA, Anikin LP, et al. (2014) Diamonds in lavas of the Tolbachik fissure eruption in Kamchatka. Doklady Earth Sciences 454: 47-49.

Griffin WL, Gain SEM, Adams DT, et al. (2016) First terrestrial occurrence of tistarite $\left(\mathrm{Ti}_{2} \mathrm{O}_{3}\right)$ : Ultralow oxygen fugacity in the upper mantle beneath Mt Carmel, Israel. Geology 44: 815-818.

Griffin WL, Afonso JC, Belousova EA, et al. (2016) Mantle Recycling: Transition-Zone metamorphism of Tibetan ophiolitic peridotites and its tectonic implications. Journal of Petrology 57: 655-684.

McGowan NM, Griffin WL, González-Jiménez JM, et al. (2015) Tibetan chromitites: excavating the slab graveyard. Geology 43: 179-182.

Xiong F, Yan, J-S, Dilek Y, et al. (2017) Origin and significance of diamonds and other exotic minerals in the Dingqing ophiolite peridotites, eastern Bangong-Nujiang suture zone, Tibet. Lithosphere (in press).

Xiong Q, Griffin WL, Huang J-X, et al. (2017) Super-reduced mineral assemblages in "ophiolitic" chromitites and peridotites: The view from Mt Carmel. Eur. Jour. of Mineralogy (in press)

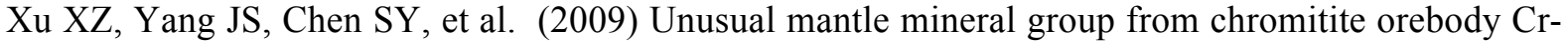
11 in Luobusa ophiolite of Yarlung-Zangbo suture zone, Tibet. Jour. Earth Sci. 20: 284-302.

Yang J-S, Robinson PT, Dilek Y (2014) Diamonds in ophiolites. Elements 10: 127-130.

Yang J-S, Meng F, Xu X-Z, et al. (2015). Diamonds, native elements and metal alloys from chromitites of the Ray-Iz ophiolite of the Polar Urals. Gondwana Research 27: 459-485.

Zhang RY, Yang J-S, Ernst WG, et al. (2016) Discovery of in situ super-reducing, ultrahigh-pressure phases in the Luobusa ophiolitic chromitites, Tibet: New insights into the deep upper mantle and mantle transition zone. American Mineralogist 101: 1285-1294. 